ZE ŚWIATA 



\title{
Македонската литература за деца (мала студија за запознавање)
}

\begin{abstract}
This short study embraces both the first sprouts of the written Macedonian literature for children (somewhere around the second part of the $19^{\text {th }}$ century), and the literary production which happens after the establishment of the contemporary Macedonian language, that is, after the 1945. Still, the main accent is on two newer books: Verses also Grow (И cmpoøume pacmam) by Alexandar Kujundziski and Jump and Skip (Скокни прескокни) by Vasil Mukaetov which is a part of the refreshed reading list as an optional book for the Macedonian language lessons in the primary schools in Macedonia. Both authors put an emphasis exactly on a child's sensitivity and such issues as character growth and maturation. In their books, they transfer the reader from childhood to adulthood unnoticeably and lightly. Their message is to help the little human in the complex process of his or her own comprehension and to show him or her that he or she are not alone in this process.
\end{abstract}

Keywords: Macedonian literature for children, sensitivity, maturation

Литературата за деца според едни води потекло од т.н. фолклор за деца со што надвладува тезата за нејзината народна основа, според други нејзините зачетоци се врзуваат со раѓањето на книжевната уметност пред и во античката епоха со што се потенцира митолошката матрица, а пак трети одвај делумно ги прифаќаат првите две гледишта тврдејќи дека оваа литература „со свои стилски обележја и педагошки облири настанува во векот на Пушкин, браќата Грим, Андерсен, Жил Верн и Керол Луис“ (Друговац, 1996, с. 7) и притоа ги нагласуваат историските, жанровските и стилските атрибути со кои оваа литература „се еманципира од своите далечни извори и се конституира како книжевна посебност“ (Друговац, 1996, с. 7).

Првите никулци на (за)пишаната македонска литература за деца ги наоѓаме во:

- дијалошките сценки на Јордан Хаџи Константинов Џинот, како и неговиот прв буквар-читанка „Таблица перваја“ во втората половина на 19 век - Зборникот на браќата Миладиновци (Загреб: 1861); 
- необјавените дванаесет песни за деца на Григор С. Прличев од 1872 година;

- фолклористичкото дело на Кузман А. Шапкарев и Марко К. Цепенков кон крајот на 19-от и почетокот на 20-от век.

Фолклорот за деца е со долга и богата традиција и како посебност не се одбегнува во класификациите ни кај В. Караџиќ, но ни кај македонските собирачи К. Миладинов, К. Шапкарев, М. Цепенков. Во Зборникот на браќата Миладиновци тој фолклор поточно тие кратки песнички-енигми се наречени играчки, или кај Шапкарев залагалки или скоропоговорки или пак кај Цепенков кој ваквите творби ги поместува во описот на детските игри. Самиот збор играчки постои и денес, вели Јадранка Владова, но ние ова име

го користиме за да означиме предмети од различни материјали, предмети кои се направени рачно (па, затоа, содржат повеќе љубов), или, пак, се направени „машински“ во фабриките (најчесто од метал, од гума и од пластика) за да им го разубават детството на децата, за да си играат со нив и поубаво да влегуваат во светот на возрасните.

Владова, 2001, с. 50

Играчките и во најсиромашната и во најбогатата куќа се еднакво важно богатство за детството. Така, слободно можеме да заклучиме дека детството на големите македонски преродбеници на 19-от век е исполнето со овие најсуптилни и најфантастични играчки создадени со помош на човечкиот дух и духовитост, создадени само од зборови. Во детските говорни игри смислата најчесто станува жртва на ритамот и на асоцијациите според звучењето. Тие се во добар дел матни и знаат „да прозвучат сосем „нелогично”, но со тоа не се губи нивната убавина која се остварува со помош на асонанците, алитерациите и римите. Целта на овие форми, заклучува Владова, е играта сама за себе (Владова, 2001, с. 51, означеното е мое).

Но, дури со усвојувањето на македонската азбука (05.05.1945) и правопис (07. 06.1945) се создадоа сите услови за издавање на првиот БУКВАР на тој новокодифициран јазик. Одлуката за објавување на еден ваков БУКВАР е донесена со Решението на Президиумот на АСНОМ од 16. 04. 1945, а со истото решение се иницира и формирање на Државно книгоиздателство на Македонија, кое подоцна е преименувано во Просветно дело. Ова книгоиздателство неколку месеци подоцна го издава делото под наслов Буквар со читанка за I одделение (96 стр.) како дело на комисијата формирана од страна на тогашното Министерство за народна просвета на Македонија и визуелно осмислена од страна на Василие Поповиќ - Цицо. Во Читанката која е интегрално вклопена во самиот Буквар се поместени, покрај народни песни и приказни, и тоа македонски и руски, уште и авторски текстови и тоа од перото на Васил Куноски, Ванчо Николески, Лазо Каровски, Слав- 
ко Јаневски, Јонче Јосифовски. Според Каталогот на издадените книги од Државното книгоиздателство на Македонија од 1945, 1946, 1947 и 1948 го$\partial u н a^{1}$, се гледа дека веќе во 1946 година излегуваат и првите книги за деца: Македонче (стихозбирка на 46 стр.) и Мице (преработена народна приказна во стихови на 24 стр.) од Ванчо Николески, потоа Распеани букви (стихови на 64 стр.) $)^{2}$ и Пионери, пионерки, бубачки и шумски зверки (приказни на 61 стр.) од Славко Јаневски, како и Овчарче (стихозбирка на 31 стр.) од Лазо Каровски во кои е воочливо влијанието на народното поетско и прозно искуство и во кои меѓу етиката и естетиката се става знак за равенство.

Едноставноста станува доблест и ознака на песните од првата збирка за деца на македонски стандарден јазик, „која во целината“, според мислењето на Мурис Идризовиќ, не настанува „од креативниот однос спрема реалноста, туку од потребите на времето "(Идризовиќ, 1988, с. 28 - означеното е мое), па во тој контекст познатите стихови, познати барем за оние кои растеа со нив, не излегуваат од рамките на т.н. „научно-сознајна песна“: „Малечко сум уште дете, / јуначе сум смело јас, / син на лична земја мила, / син на Македонија." (цитирано според Идризовиќ, 1988, с. 28). Всушност, Ванчо Николески како еден од првите учители на македонски јазик во селата во ослободената Дебарца, го понесува со сета одговорност и товарот на „татко и прво перо“ на литературата за деца во Н. Р. Македонија (Друговац, 1996, с. 82). И збирката „Овчарче“ од Лазо Каровски, и покрај ласкавите зборови на Димитар Митрев, од денешен аспект, според Идризовиќ, „има повеќ литературно-историски карактер, додека нејзината литературна вредност е скромна“. Таа е интересна „како документ за тематската и изразната определеност“, зашто збирката е во функција на воспитувањето, поентира Идризовиќ (Идризовиќ, 1988, с. 108 - означеното е мое). „Поетот се свртува кон искуството на македонската народна песна, но постои и обид за раскинување со нејзиниот вокабулар и мелодиски образец“, вели Друговац (Друговац, 1996, с. 197).

Сосема поинакво е искуството што го нуди Славко Јаневски. Во неговите првообјави се чувствува насоченоста кон една „игра“, но и вткјувањето на сериозни „елементи на модерност“ (Идризовиќ, 1988, с. 82 - означеното е мое) и затоа тој го носи приматот на „втемелувач на модерниот збор и стих во македонската поезија и проза“ за деца (Идризовиќ, 1988, с. 94). Според Јаневски литературата за деца не смее да биде дидактична. „Јас никогаш не се трудам да ја направам таква - вели тој. - Меѓутоа, ако учителите и професорите во некој од моите текстови пронајдат нешто што ќе ги поучи децата слободно нека се послужат со тоа“ (цитирано според Друговац, 1996, с. 139).

${ }^{1} \mathrm{http} / / /$ www.slideshare.net/OnlineEduCenter/katalog-8590003 [преземено на 26.09.2018].

${ }^{2}$ http://okno.mk/sites/default/files/097-Raspeani-bukvi-Slavno-Janevski.pdf [преземено на 26.09.2018]. 
Токму таква е и приказната „Цар Тифус, принцезата треска и другите лоши владетели“ (од збирката Пионери, пионерки, бубачки и шумски sвер$\kappa u)$ која низ играта ги подучува ненаметливо децата на хигиена преку необичното искуство на момчето Кочо. Овој Кочо е „стар непријател на водата и сапунот“ или пак сапунот и водата се негови најголеми непријатели и како таков се заразува со сите можни/познати болести при што на крај завршува и во болница.

Така, покрај пионерите и пионерките свое вистинско место добиваат и животните и растенијата или како што вели и самиот Јаневски бубачките и шумските sверки, а во оваа приказна и водата и сапунот. Или поточно обратно. Доживувањата на бубачките и шумските sверки стануваат доживувања на малите пионери и пионерки. Во таа 1946 година треба да се спомене и збирката „Народни песни за деца“ (распослана на 51 стр.) во редакција на Ванчо Николески и Јонче Јосифовски, а со илустрации на Славко Јаневски.

Но, овој текст е обид да покаже како од тие први книги за деца на македонски стандарден јазик, па преку култната Шекерна приказна (1952) на Славко Јаневски, изградена на матрицата на македонската народна сказна со многу контаминации од европската народна и уметничка сказна, па сѐ до некои најнови, како онаа На nam за Таратамбо (2016) на Трајче Кацаров, се изодува пат долг нешто повеќе од 70 години. И како волшебната земја на бубачките и шумските sверки (на Јаневски) израснува во уште почудна со необично име - Таратамбо (на Кацаров) која наликува и на онаа Недојдија од Петар Пан и на онаа Земја на чудата во која пропаѓа Алиса, па и на земјата Дембелија кон која се упатува Пинокио, а и на селото Негобило во кое се раѓа шеќерното дете на Славко Јаневски.

Од пред неколку години има сериозна иницијативата за ревизија на лектирите од второ до деветто одделение од страна на Бирото за развој при Министерството за образование и наука која, ете, годинава финишира и со некои конкретни предлози и со нова програма за лектирна понуда. Во неа рамо до рамо со познатите имиња и наслови и од македонската, но и од светската литература за деца, се понудија автори и книги кои треба да се измерат по однос на читливоста и прифатеноста со веќе етаблираните од типот на: Зоки Поки или Девојките на Марко од Оливера Николова, Касни - порасни од Петре М. Андреевски, Шекерна приказна од Славко Јаневски, Големи и мали од Бошко Смаќоски, Споменка и Марта од Горјан Петревски, но и со Пипи Долгиот Чорап од Астрид Линдгрен или Пинокио од Карло Колоди, Малиот прини, од Антоан де Сент-Егзипери.

Така, во 2013 година, во првиот ревидиран список лектири влегоа и последните добитници на наградата Ванчо Николевски на ДПМ, Ефтим Клетников со Цар Салтан (награда за 2010) и Билјана Станковска со Вистин- 
ска приказна за исчезнуването на приказните (награда за 2011). Првата е создадена по мотивите на истоимената сказна на Александар Сергеевич Пушкин и е стихувана драма во шест чина, со наратор кој нѐ води низ дејството, а која уште при првиот прочит се чини погодна за сценско поставување. Приказната на Станковска, која отворено зборува за стравот од целосно исчезнување на приказните, успева ненаметливо да пренесе и важни одделни дидактички односно хуманистички пораки, како тие за важноста на семејството, љубовта, благородноста, чесноста, остварување на ветеното. Исто така, на идните читатели им се даде можност заедно со своите наставници покрај светските и македонските класици да изберат и некој од поновите наслови на македонски автори, како Сакам книга од Александар Кујунџиски, инаку преведена/препеана на уште шест јазици на заедниците во Р. Македонија (албански, турски, српски, ромски, влашки/аромански и босански), а која од 2016 година ја има на уште четири други (словенечки, хрватски, црногорски и германски) $)^{3}$ или Златното јаболко и други бајки од Христо Петрески.

Во меѓувреме се напишаа, се отпечатија нови книги. Се случија и исклучителни изданија како она посветено на собраните дела на Васил Куновски (2010) кое нѐ потсети на многу (под)заборавени работи врзани со него како човек, сопруг, татко и дедо, но пред сѐ како голем поет за деца во Македонија, препеан и на неколку јазици (српски, хрватски, словенечки, албански, турски и руски). Нѐ потсети на неговата исклучителна посветеност на стихот. Нѐ фрли во размисла дека забораваме да им кажуваме и читаме на своите деца, дека забораваме да им ги кажуваме нашите песни, песните со кои расневме, песните на нашето детство, кои за нас ги напиша токму тој - Васил Куноски.

Некои од авторите прославија сериозни јубелеи со убави изданија, како она на собраните дела за деца на Оливера Николова подготвено од страна на Детска радост (2013) по повод 50 години творештво, како и по повод 50 години од Зоки Поки, организирано во три книги (Тu чука ли срцето за мене?, Ми чука ли срието за тебе? и Ни чукаат ли сриата за нас?) со осум наслови. Таа тоа и го заслужува зашто во периодот на тие свои интензивни 50 години творење, во кои покрај за децата пишува и за возрасните, покажува како во своите текстови треба да се почитува детето.

Од друга страна, ДПМ ревносно секоја година ја следи продукцијата на книги наменети за детското читателско око и се труди наградата Ванчо Николески да отиде во вистински раце. Но, и покрај сѐ, во последните години т.е. од 2010 па наваму, оваа награда сѐ уште је нема добиено не-

3 „Сакам книга“ (2006) е преведена и објавена на: албански (Dua Libër), турски (Kitap istiyorum), српски (Хоһy къигу), ромски (Mangava lil), влашки, аромански (Voi carti), босански, бошњачки (Volim knjigu), словенечки јазик (Ljubim knjigo), хрватски (Zavolih knjigu), германски (Ich liebe das Buch) и на црногорски (Želim knjigu). 
кое ново име на книжевната сцена насочена кон детето како читател. Така Панде Манојлов (1948) за збирката поезија Сонувај добрина (2012), Александар Кујунџиски (1946) исто така за стихови под наслов И строфите растат (2013), Стојан Тарапуза (1933) за стихозбирката Насликано време (2014), Велко Неделковски (1946) за книгата, инаку серија од четири мини-романи, Златко-Златеи (2015), Александар Поповски (1932) за книгата И по стопати (2016) и Васил Мукаетов (1941) за стихозбирката Скокни, прескокни (2017) се добитниците на оваа престижна награда на ДПМ. Сите се автори кои имаат 70, а некои од нив и нешто повеќе од 80 години.

Инаку, на сите деца им треба стекнување навика најпрвин за слушање, а потоа и за читање сказни, приказни, книги. Во тој поглед особено се значајни сликовниците преку кои детето почнува да го развива чувството за потреба од слушање кое во поголема возраст прераснува во потреба за (самостојно) читање. А сликовница е претходница на книгата за деца и на книгата воопшто. Таа е: „книга во која илустрациите играат значајна улога во раскажувањето на приказната. [...] Она што ја прави сликовницата уникатна уметничка форма е токму фактот што текстот и сликата придонесуваат за целосното значење, преку ритамот, движењата, тензијата, изгледот на страната и целокупниот дизајн“ (Тодорова, 2012, с. 49). Всушност, специфичната поетика на сликовницата го прави читателот на сликовницата истовремено да е и гледач и слушател и од таа перспектива се создава и идниот нов читател. Кога приказната за деца се чита на глас таа наликува на театарска престава или филм, вели Рита Оитинен (Rita Oittinen) (според Тодорова, 2012, с. 51). Во тој поглед денешното дете многу повеќе / многу поинтензивно го прима светот визуелно. Затоа и некои од книгите-добитници на наградата Ванчо Николески се обидуваат да посветат вистинско внимание и на визуелната страна, поточно на нејзиното ликовно-графичко обликување.

Во оваа мала студија за запознавање со најсовремената македонска литература за деца се осврнуваме на две по/најнови книги, од кои едната е и дел од најновиот освежен список лектири во делот на изборните книги. Сепак, за вистинско придвижување и освежување треба да се прашаат и децата. Дали тоа што ние возрасните и компетентните го избираме за нив проаѓаа и кај нив? Дали се читливи, дали се возбудливо читливи, дали се игриви, дали ги поттикнуваат на размисли? Тие се на потег!!!

Да се учи да се брои, да се учи да се чита, За да се порасне вистински

110-та по ред објавена книга на Александар Кујунџиски, под наслов И cmpoøите растат е пишувана за денешното/современото дете кое како 
што расте ги совладува паралелно и буквите (31 во македонската кирилица) и бројките (15 во оваа концепција на поетот). И cmpoøите pacmam coдржи 32 песни (првите четири песни се со по една строфа во двостишја, а последните две во 15 строфи од четиристишја) кои буквално имаат „строфи кои растат“, исто како што растат т.е. како што треба да растат и самите читатели, оние од најмалите до помалку малите и поголемите, па сѐ до големите. Така што, во рекламата за оваа книга стои дека таа е наменета за децата од I-VI одделение во основните училишта.

Поезијата и математиката се две сродни дисииплини, истакнуваат и По, и Бодлер, и Малерме. Според ваквата концепција, зборовите се јазички симболи со кои можат да се вршат прецизни мисловни операции, како во математиката. Така токму математичката точност на стилот ги вбројува Бодлеровите Цвеќиюа на злото во редот на најстрогите книги на европската лирика. Се смета дека тенденцијата за цврста и логичка архитектура на една збирка т.е. строго утврден распоред на различните песни во неа, станува општо место во модерната поезија. Овој концепт за една цврста и логичка поетска архитектура го развива и Александар Кујунџиски во својата збирка И стробите растат.

И како што познатата збирка на Петре М. Андреевски Касни - nорасни (1992) се обидува да го направи овој свет поинтересен, пошарен, но и повкусен, зашто малиот читател го става пред дилемата кое овошје е (по) омилено, кое овошно шеќерче да се касне денес, а кое да се остави за утре, но при тоа лека-полека, без голема мака да се порасне, така и збирката на Александар Кујунџиски И строфите растат (2013) му покажува на малиот читател како со буква по буква, како со збор по збор, најпрвин изговорен, а потоа и прочитан, почнува да се создава мислата, а потоа како мислите почнуваат да се нижат, строфите да растат, стиховите да се бројат и пребројуваат, а приказните од мали да стануваат поголеми, од едноставни посложени. Како и животот! И овде има што да се касне за да се порасне (особено во песната Ново мачешко доба), но мора и да се учи да се брои, да се чита, мора да се научи и да се брои и да се чита, ако се сака да се порасне вистински!

Целата збирка, покрај строгата математичка формула секоја наредна песна да има една строфа повеќе од претходната, и така од песна од една строфа на крај се случува песна од 15 строфи, како и правилото секоја да има свој пар, е концепирана баснолико. Поетот Кујунџиски своите басно-песни ги гради од аспект на структурната нишка, дијалошката фрекфенција, изборот на ликовите, шестосложниот стих, темата. Така што со чисто срце може да се каже дека овие баснолики песни ја надминуваат веќе познатата шема на басна на Езоп, на Обрадовиќ, на Крилов, на Лесинг. Оваа збирка создава една своја басна-песна во која е преточено времето во кое живее и поетот, но и детето. Особено кога во своите поетски слики Кујунџиски ги вградува и моментите на (нај)современата технологија кои 
стануваат дел од животот на најмалите и дел од нивното детство. Па така, сојката која везден интернет следи, ѝ ги враќа туѓите јајца на кукавицата преку брза пошта, а во разговорот меѓу дивиот и питомиот гулаб, овој вториов му дава совет на својот роднина што поскоро да загрее столче и да почне компјутер да учи.

Инаку, басната води битка за опстанок. И таа се бори со експанзијата на визуелните, печатените и електронските медиуми кои се толку моќни што ја потиснуваат книжевноста. Но, поетските басни се многу привлечна литература за децата, затоа што имаат весела содржина којашто предизвикува незапирлив кикот и солзи во детските очи. Овие стихови на Кујунџиски пред сѐ говорат за нашето културно и животно искуство, и за малите-големи работи кои му даваат суштина на животот. Тие не се само педагошка литература, ниту декларативна, ниту пак естетска енигматика, тие се стихови кои носат радост и поука истовремено.

Кај Кујунџиски не се среќаваат оние ликови на животни кои се каратеристични за Езоп или за Ла Фонтен, а и ако ги има тогаш тие се преобработени и така преобликувани добиваат други значења. Затоа басновитите песни на Кујунџиски се полни со искристализирани типични атрибути на ликовите животни кои влегуваат во необични и несекојдневни разговори, па почнуваат да се надмудруваат смокот и волот, да се расправаат мувата и пчелата чие зуење е пополезно, да се споредуваат зелениот гуштер и милното срнче кој е поубав и кој има поубава опашка, да се расправаат гасеницата и зебрата кој подобро ги познава сообраќајните правила и кој има повисока сообраќајна култура, да се докажуваат полжавот и бикот чии рогови се посилни, да се закачаат фазанот и лилјакот, да се докажуваат скакулецот и жабата кој има поголем скок. Сите тие го развиват започнатиот сериозен дијалог во вистински книжевен и животен симпозиум. Римата запазена во вториот и четвртиот стих, ритмичноста, вицот, шегобијноста, хуморот, трагите од познатите поговорки, и сето тоа организирано во четиристишни строфи со беспрекорен шестерец ги прават овие песни лесни за паметење, но и игриви и забавни.

Детето како лик е една вистинска иновативна карактеристика во творештвото на баснописецот Лесинг, зашто, иако басните во прв ред се пишуваат за децата, тие не ги опфаќаат децата како ликови. Кај Александар Кујунџиски ликот на детето се крие зад ликовите на сите оние животинки, инсекти, бубачки, тревки кои во неговите поетски слики и баснолики приказни се именувани со деминутивните форми како: мравче, кутре, штурче, маче, дождец, пиленце, срнче, гуде, змејче, глувче, петле, зајаче, врапче, или преку галовни форми од типот: милениче наше, галениче златно, златни глувчиња.

Во овој опус од 32 песни има и доволен број тажни приказни, но Александар Кујунџиски, како впрочем и Ханс Кристијан Андресен, никогаш не 
е песимист. Секогаш во неговите стихови провејува надежта дека, и покрај сите тешкотии во животот, вреди да се живее, дека животот е убав и богат и дека оној кој со отворено срце ги прима и малите и големите дарови од животот никогаш од него нема да биде излажан, дека добрите луѓе токму поради својата добрина секогаш ќе бидат среќни. Големиот Андерсен, освен типичните животни кои дотогаш беа ликови во приказните/басните, воведува и некои нови/свои. Па така, кај него се јавуваат полжавите (Среќно семејство), глувците (Клин чорба), лебедите и патките (Штркови, Грдото пајче). Во своите приказни ги воведува како ликови и растенијата воочувајќи ги сличностите меѓу нив и луѓето според бојата, цветот, држењето како во Цвеќето на малата Ида, Семејството од соседството или Полжавот и розиното дрво во кои се јавува розата т.е. розиното дрво како лик. Андерсен во своите приказни оживува и многу предмети, како играчки, разни фигури, стари куќи, секојдневни предмети, портрети, статуи, ормари, огледала, садови/посатки како во Оловниот војник, Црвените чевличиюа, Старата куќa. Истата страст ја забележуваме и во стиховите на Кујунџуски, па така штурчето се жали дека му е многу жешко, штркот стои на една нога зашто е шкрт, волот плаче зашто не му се допаѓ името, враната среде долот шарен, под стариот орев, сака да направи море, бизонот во базен се нурнува, а кучето Добармен бара куче - чувар.

„Прекрасно е ако литературата може да ѝ конкурира на жестоката визуелност која неконтролирано го освојува светот на детството. А дидактичноста на литературата за деца е само обратен мимезис, во неговата смисла да се препознае светот“, ќе рече Владова во својата книга Литература за деца (Владова, 2001, с. 17). И строфбите растат на Александар Кујунџиски многу успешно со помош на песната им ги открива малите тајни на животот и истовремено со убавиот збор се обидува да ѝ пркоси на визуелноста.

\section{Клучалката на детството е во секој човек}

Стихозбирката Скокни, прескокни на Васил Мукаетов (2017) нанижува стихови со една единствена цел: „Да се скокне и прескокне! / Што побргу да се расте, / што повеќе да се знае“. Впрочем како во самиот живот! Така, овде навистина има што да се скокне и прескокне, што да се прочита и дочита, што да се учи и подучи, ако се сака да се порасне вистински!

Како централна песна во која е вдомено и мотото за растењето е онаа која пее за тоа дека оној момент кога бабата како најголема раскажувачка на сказни ќе си замине на пат, тогаш на детето му останува едноставно да скокне и прескокне и од љубопитен слушател на сказните извезени од бабините зборови да стане страсен читател на сказните скриени во книгите 
навезени со зборови. Ама за тоа, како што пее Мукаетов, треба: „Куќата да биде отклучена, / треба азбуката / да биде научена“ (Се снаоѓa, сказни пронаоѓa).

Стиховите Скокни, прескокни се вистински показ за разбуденото дете во авторот, за еден автор кој никогаш не сака да престане да размислува како дете, за автор кој знае да го разигра, но и да го по(д)учи детето низ таа разиграност, за автор кој поучува додека зборовно си игра и си игра додека мудрува. Зашто како што пее поетот: „Така било отсекогаш, / така и довек. / Клучалката на детството / е во секој човек! / Па така ќе се случува / Вечно да се отклучува!“ (Клучалката на детството).

Скокини, прескокни се обидува да го фати ритамот на новото дете, но и да му (рас)каже на тоа ново дете и за детето од времето на неговите родители, но и на неговите баба и дедо, па низ песните го носи и на панаѓур, и на циркус, му кажува како се мери времето и со часовници на рака и со мобилни, но и со песочни часовници, му пее за лазарките, девојките-водарките. Скокни, прескокни вешто создава и овчарска, па и рибарска песна, а и песна за еден готвач со готова листа за луѓе триста.

Ритамот е фатен и за тоа ги имаме:

- пчелката онаа која е главна во песната Од цвет на ивет - до мед и која освен што е дел од природата, станува препознатлива и како печат кога наместо оценка-бројка се става на рачето на детето или во тетратката на малото учениче кога сака да се покаже, како што се пее и во последниот стих, дека: Овој е вреден ко пчела!;

- пајакот кој не плете мрежа, туку автомобилите низ градот ги реди и подредува (Пајак среде град);

- количката во супермаркетите која истовремено е и необично превозно средство и голема корпа за пазарење (Сu пазариш, се возиш);

- лифтот кој е магично превозно средство и кој како ракета се движи, лета горе-долу (Се возиш на кат);

- детската соба која многу пати станува еден огромен пиратски брод (Зад нашите врати - пирати), а сонцебранот - шарен детски ресторан (Тие пливаат).

Како најголем грев во литературата за деца се посочува нејзината дидактичност/поучноста. Впрочем таа, самата за себе, не е воопшто лошо обележје на литературата за деца. „Прекрасно е ако литературата може да ѝ конкурира на жестоката визуелност која неконтролирано го освојува светот на детството. А дидактичноста на литературата за деца е само обратен мимезис, во неговата смисла да се препознае светот“, пишува Јадранка Владова во својата книга Литература за деца (Владова, 2001, с. 17). Па така Мукаетов постојано подучува, па кога пее за моливчето и гумичката кои „чуда испишуваат, / грешки исправуваат. / Затоа во кутичето грижливо се чуваат!“ (Не може молив без гумичка), тогаш на овие распеани предмети 
им дава и една нова визура и во песната Чекор напред - еве современ заплет, која се чита како еден диптих со претходната, пее вака: „Моливчето ти е тастатура, / Буква до буква на твојот таблет. / Гумичката? / Само ќе типнеш на «дилит» / Што требало - избришано. / Сѐ е во ред“.

Или кога на анимираните јунаци им подотвора врата и тие така комотно се вселуваат во неговите стихови. Па така поетот Васил Мукаетов во секојдневната игра на своите два внука Матеј и Калин како да ги гледа згодите и незгодите на популарните Том и Џери. Или како во секое дете да гледа еден мал (скриен/прикриен) Пинокио. Мукаетов пее и за тоа дека новото дете е вистински подготвено за една нова Црвенкапа која на својата баба ѝ носи колачиња и кока-кола и која на тој пат не тргнува без таблет или мобилен, но и дека во својот Матеј гледа една верзија на популарниот Бен Тен (10), а во својот Калин еден крајно модерен Капетан Кука од приказната за Петар Пан.

Сепак, играриите не застануваат тука, туку од детската соба се нурнуваат во морскиот свет, па така некогашните сказни, онаа за малата Сирена на Ханс Кристијан Андерсен или онаа за цртаното рипче Немо на Волт Дизни продукцијата, добиваат свои нови другари во стиховите каде пливаат и лошата скорпија, за која Муакетов вели дека е комарец во океан, и ежињата морски, и октоподот што се мрешка, со крупни очи што намига и ти се смешка, и китовите, и ајкулите, а сите тие најсреќно живеат во лудориите на Матеј и Калин. И потоа, од морскиот свет со уште едно скокни, па прескокни, еве нѐ во стиховите за лавчињата мали, кои сѐ уште се тука, на нашата планета, но и за разноразните предисториски влечуги чудни, кои ете уште живеат, освен во учебниците и книгите, и во песничките на Мукаетов и нѐ држат будни.

Добрата литература за деца става акцент токму на чувствителното и карактерното растење и созревање. Таа, незабележително, лесно, го пренесува читателот од брегот на детството до брегот на возрасните. Во тоа лежи и нејзината порака - да му се помогне на малиот човек во сложениот процес на себеспознавањето и да му покаже дека во тој процес тој не е сам.

А токму овие стихови на Васил Мукаетов ставаат акцент на тоа чувствително и карактерно растење и созревање.

\section{Уште некој збор за македонската литература за деца (наместо заклучок)}

Но повторно да им се навратиме на почетоците за да кажеме уште нешто. Славко Јаневски „ги удира темелите и во литературата за деца и во литертурата за возрасни“, вели Јадранка Владова (Владова, 2001, с. 19), мис- 
лејќ́ на македонската, особено со неговата проза Улица објавена 1950 година ${ }^{4}$.

Но не смее да се заборават и сите оние кои стоеја со него рамо до рамо, како Ванчо Николески, Васил Куноски, Борис Бојаџиски, Глигор Поповски, Цане Андреевски, Видое Подгорец. И дека скоро сите, со исклучок на Јаневски, беа најпрвин учители, а потоа станаа и писатели, пред сѐ за деца. Така што, отворено кажуваме дека, заедно со Славко Јаневски, и Ванчо Николески и (особено) Васил Куноски се втемелувачите на македонската литература за деца.

Белото ичганче, Волиебното самарче, Мице, Големи и мали, Втора смена, Марта се вистински литературни бисери на македонската литературна ризница за деца. Но поразителен е фактот дека литература за најмладите читатели се создава поретко во Македонија, со исклучок на последните две-три години. Писателите не пишуваат за деца зашто ова литература не се третира сериозно, тиражите се мали, медиумска поткрепа нема, а на авторите се гледа како на писатели од втор ред.

Како еден од обидите да се направи нешто повеќе за литературата за деца во Македонија, некаде во февруари 2010 година се одржа трибина во Културниот центар Феникс на темата Македонската литература за деца и млади денес. Трибината ја водеше Марија Таушанска, уредник на прилогот за деца Колибри во дневниот весник Нова Македонија, кој е единствен од ваков вид во Македонија. Како учесници беа писателите: Горјан Петревски, Велко Неделковски и Ванчо Полазаревски, како и Перо Миленковски, поранешен долгогодишен уредник на Колибри, Марија Тодорова ${ }^{5}$, преведувачка и соосновачка на издавачката куќа за литература за деца Вермилион од Скопје ${ }^{6}$, Миле Топуз, илустратор на многу книги за деца и Христо Петрески, кој во 2009 година ја доби наградата Ванчо Николески за својата книга за деца На умните не им требаат скали за качување.

Пасивност, дисконтинуитет, изолираност, непостоечка креативна и генерациска обнова, стереотипи, локална омеѓеност... Таква е, за жал, состојба на литературата за деца и млади во Македонија, се сложија присут-

4 Во овој контекст треба да се истакне и сознанието дека Шеќерна приказна на Славко Јаневски е вистински пример за авторска/уметничка сказна која е споредлива со такви текстови од светската литература, како на пример со популарната приказна Пинокио на Карло Колоди. Види Мојсова-Чепишевска В., 2000.

5 Тодорова е меѓу ретките автори што теоретски се осврнуваат на творештвото за деца. Нејзината книга Литературата за деца и културната разноликост (Скопје 2010) се занимава со теоретскиот аспект на пораките за другоста во литературата за деца во Македонија создадена по 2001 година.

6 Досега, вели Марија Тодорова од Вермилион, пристигнуваат одвај две-три книги на конкурсот што неколку години по ред го распишуваше оваа издавачка куќа. Конкурсот се објавува со надеж дека македонски автори ќе најдат мотив да создаваат за децата. Но еве и тој конкурс замира! 
ните на таа трибина. Иако на оваа тема повеќе би ѝ одговарале зборовите слободна мисла, креативност, едукација, прифаќање на разликите, духовен натпревар, напредок. Ванчо Полазаревски, кој освен што пишува за деца, беше и долгогодишен уредник на списанието за тинејџери Тин шема, смета дека пишувањето за најмладите е многу одговорна работа што бара многу внимателен пристап. „Да се напише квалитетно дело е вистински потфат. Секој автор треба да го пронајде детето во себе, но не да пишува за своето детство, туку за актуелни теми интересни за денешните генерации“, истакнува Полазаревски ${ }^{7}$. Според него, важен е и приодот кон детето, тоа да се почитува како личност и како рамноправен соговорник. Полазаревски иднината на литературата за деца ја гледа во нејзиното осовременување, во користењето на Интернет на еден поинаков, едукативен начин. „За идните генерации ако треба и на Силјан Штркот ќе му ставиме електронски крилја, за да може полесно да „лета“ во 21-от век“, вели тој.

Велко Неделковски, кој е автор на сценарија на своевремено многу популарните серии за деца, снимени по неговите романи Втора смена и Булки крај шините, смета дека македонската литература, и покрај тоа што по квалитетот е рамноправна со европската и светската, страда од анонимност, а тоа значи дека таа не е презентирана надвор. Тој посочи дека има многу книги погодни за екранизација, но сѐ уште во Македонија не е снимен филм за деца, по примерот на Хари Потер ${ }^{8}$. Во половина век кинематографија Македонија сѐ уште не може да се пофали со снимен филм за деца, а во земјава постојат само два театра што на репертоарот имаат детски претстави. Од друга страна, досега никој не се обиде да направи романизирана биографија за Марко Крале9, од која потоа можеше да се изроди и филмска верзија по примерот на Господарот на прстените.

7 Види „Каде се загубија приказните” во Нова Македонија. Скопје: бр. 21917, 23.02.2010.

${ }^{8}$ Во овој контекст треба да се споменат: ТВ серијата од 1975 година Волшебното самарче во режија на Ацо Алексов и Игор Џамбазов во главна улога, потоа македонска серија за деца и млади Втората смена снимена 1988 година, според истоимениот роман на Велко Неделковски (која може во парчиња да се најде и на интернет) и ТВ серијата Големи и мали (роман на Бошко Смаќоски од 1966 година) работена на самиот крај на 20 век т.е. 1999/2000 во режија на Душко Наумоски.

9 При тоа се има предвид дека на епската поезија, особено преку процесот на создавање поетски/епски биографии на епски јунаци, се гледа како на претходник на романот. Така, сто и седумте песни и четириесет и едното предание и кажување кои го варираат популарниот лик на Марко Крале и кои Кирил Пенушлиски (Марко Крале - легенда и стварност. Скопје: Мuсла, 1983) ги презел од повеќе извори и тоа од кај Миладиновци, Цепенков, Верковиќ, Шапкарев, Икономов, браќата Молерови, Драганов, Стоилов или ги запишал од индивидуални или група пеачи, допуштаат портретирање на овој популарен епски лик. Еден таков пример на осовременета легенда наоѓаме во книгата „Приказната за Вилхем Тел“ на Јирг Шубигер која е добитник на швајцарската награда за книга за млади во 2005. Имено, и на самата корица на книгата како порака или реклама стои: „Легендата за Вилхем Тел во Швајцарија е како Крале Марко во Македонија“. 
„Во светот, литературата за деца е најкомерцијална зашто е врзана со филмската индустрија, со индустријата за играчки..., но кај нас“, вели Христо Петревски од Феникс, „тоа е невозможно зашто пазарот е мал и специфичен“. За Горјан Петревски, најтиражниот писател за деца во Македонија, автор на популарниот роман Марта, тинејџерите се најискрената публика. Затоа, според него, авторот треба да знае како да им го задржи вниманието.

Сепак, особено од оваа трибина треба да се истакне мислењето на Ванчо Полазаревски во кое се потенцира потребата од свртеноста на писателите кон другите медиуми.

Во однос на читањето, детето денес пред себе ја има бесконечноста на електронските патишта кои не познаваат граници. Тие нему му нудат еден друг вид читање. Читање што е во сообразност со новото време и читање кое за него е далеку, далеку поатрактивно“, вели Полазаревски. „А во тоа читање нема повеќе маало, нема улица за игра, нема џамлии... и затоа се залудни сите носталгични лелекања над едно време што си ја одиграло својата улога. Денес децата можат само да бидат збунети од инсистирање на таа носталгија. Тие читаат трејлери на најнови филмови, тие денес се веќе длабоко во светот на Алиса, не се само пасивни читачи, тие имаат можност да бидат активни, многу поактивни од порано, учесници во градењето на својата култура,

критикува Полазаревски (2010).

Тоде Илиевски, добитникот на наградата на ДПМ за најдобра книга за деца и за млади Ванчо Николески во 2010 година, смета дека востановувањето фестивал на детската книга во Македонија, судејќи по светските и по регионалните искуства, би ги мотивирало и авторите и читателите. Националниот фестивал на детски книги во Сливен, Бугарија, Фестивалот на детскиот хумор во Лазаревац, детскиот фестивал во Нови Сад, и двата во Србија, фестивалот Монте либрич во Пула, Фестивалот на бајката во Огулин, двата во Хрватска, се само дел од низата фестивали посветени на детето и на пишаниот збор, кои секоја година се одржуваат во соседните земји.

Од друга страна, факт е дека култната книга Зоки Поки на Оливера Николова кој првпат се појавува во 1963 година сѐ уште никој не ја заменил. Зоки Поки сѐ уште не може да оди во пензија. Причината за неговата голема популарност можеби лежи и во самата дилема околу влогот на реалното и фантастичното во приказните за Зоки Поки што донекаде ја разрешува самата авторка истакнувајќи дека тие изгледаат како да се изградени врз набљудувањето на детското секојдневие при што си/ни го поставува клучното прашање: „дали едно набљудување, така голо, може да прерасне во литература ако ја нема топлата рака на фантазијата“ (цитирано според 
Друговац, 1996, с. 335). Така што тоа содејство на две проекции, на две перспективи е, според самата авторка, и со цел да се постигне естетска ефикасност во самото раскажување. Еве како Миодраг Друговац во своја книга Македонската книжевност за деца и младина го карактеризира ова веќе од денешен аспект класично дело на македонската литература за деца:

Во Зоки Поки со полн спонатанитет се усогласени атрибутите на реалното и фантастичното, стварното и измисленото, за да триумфира играта, за со неа да се остварат поетичките задачи на модерната проза за деца. Приказната, која и да е, има свој инфантилен тек, но во рамките на стандардот со кој се претпочита детскиот аспект, во рамките на едно слоевито раскажување во кое непрекинато се чувствува духот на детството. Приказната, која и да е, не крие дека играта сака да го забавува детето; забавувајќи го, пак, таа не губи од вид дека тука и таму детето треба и да се замисли над она што е напишано, оти во спротивно напишаното се обесмислува станувајќи игра-самоцел, од која не се гледа вистинската творечка намера на писателот, неговата идеја, неговата хуманистичка цел, педагошка и естетска смисла на приказната.

Друговац, 1996, с. 335

Всушност Зоки Поки е една многу зрела и самобитна проза за деца која без голем напор му се наметнува и на малиот/детскиот и на големиот/возрасниот читател.

Во духот на новите интереси кај децата кои се сѐ повеќе свртени кон другите медиуми, како телевизијата, компјутерите и копјутерските игри, во 2003 година Загорка Поп-Антоска направи адаптација на книгата Зоки Поки и во продукција на АУДИОЛАБ излезе мини-серијата под ист наслов во 10 епизоди во времетраење од 12 до 15 минути секоја одделно, музички обоена од страна на Тоше Поп-Симонов, а во режија на Александар Илиев ${ }^{10}$. И тоа е она што го имаме во очекување на она што ќе го имаме, а тоа е тв-серијата како проект финансиран од Агенцијата за филм на Р. Македонија, во режија на Александар Поповски.

${ }^{10} \mathrm{https} / / / w w w . y o u t u b e . c o m / w a t c h ? v=y 3 y G c 4 X V k R g$ [преземено на 26.09.2018] — прва епизода, https://www.youtube.com/watch?v=kD_YxkF-niw [преземено на 26.09.2018] — втора епизода, https://www.youtube.com/watch?v=H4T7Z6oSaRU [преземено на 26.09.2018] — трета епизода, https://www.youtube.com/watch?v=yTHeVwnyGzM [преземено на 26.09.2018] четврта епизода, https://www.youtube.com/watch?v=57E2SgaXiPs [преземено на 26.09.2018] — петта епизода, https://www.youtube.com/watch?v=oqtqZKoeVRA [преземено на 26.09.2018] шеста епизода, https://www.youtube.com/watch?v=AXNRABqHl3Q [преземено на 26.09.2018] — седма епизода, https://www.youtube.com/watch?v=gtR_qmO3JHk [преземено на 26.09.2018] — осма епизода, https://www.youtube.com/watch?v=FOZ-5lVkpl0 [преземено на 26.09.2018] деветта епизода, https://www.youtube.com/watch?v=IxLMGBuJ3v4 [преземено на 26.09.2018] — десетта епизода. 
Но, останува да одsвонува прашањето: Зошто и по цели педесет и пет години никој не се зафати на Зоки Поки да му даде книжевен другар, книжевен наследник или контрапункт? Се нема инспирација, се нема храброст?

Навистина: 3ОШТО?

\section{Литература}

Čačko P., 2000, Slikovnica, njezina definicija i funkcije, in: Kakva je knjiga slikovnica: zbornik radova sa savjetovanja povodom Međunarodnog dana dječje knjige održanog 26. travnja 1999. u Zagrebu, Javor R., prired., Zagreb.

Cashdon S., 1999, The Witch must die - how fairy tales shape our lives, New York.

Drndarski M., 1987, Voved, Narodna bajka u modernoj književnosti, Beograd.

Haramija Ž., 1978, Skok iz medija animiranog filma u medij slikovnice, "Umjetnost i Dijete", br. 57, Zagreb.

Liti M., 1994, Evropska narodna bajka, Beograd.

Oblak S., 1971, Slikovnica - prva knjiga djeteta, "Umjetnost i Dijete", br. 3, Zagreb.

Владова J., 2001, Литература за дец, Скопје.

Денкова J., 2011, Книжевност за деца, Штип.

Димова В., 2012, Естетика на комуникацијата и литературата за деца, Скопје.

Друговац М., 1996, Македонска книжевност за деца и младина, Скопје.

Ивановска Г., 2006, Зад превезот на сказните во Мираж 15, Скопје.

Идризовиќ М., 1988, Македонската литература за деца, Скопје.

Мојсова-Чепишевска В., 2000, За уметничката сказна „Шеќерна приказна“ во Литературни преокупации, Скопје.

Мојсова-Чепишевска В., 2010, Вредната на Васил Куноски рака не само што пишува, туки и игра вака во Куноски, Васил. Собрани дела, Скопје.

Мојсова-Чепишевска В., 2013, Пинокио и Шеќерното дете во Годищен зборник 2012, Штип.

Мојсова-Чепишевска В., 2014, Актуелните состојби во македонската титература за деца во зборникот XL Научна конференција на XLVII Меѓународен семинар за македонски јазик, литература и култура, Скопје.

Мојсова-Чепишевска В., 2014, Нови теми и пристапи во најновата хрватска титература за деца во Македонско-хрватски книжевни, културни и јазични врски, Скопје.

Полазаревски В., 2010, Каде се загубија приказните. „Нова Македонија”. Скопје, бр. 21917, 23.02.2010.

Прокопиев А., 1997, Патувағьта на сказната, Скопје.

Тодорова М., 2012, Преведуваюето за деца како меѓукултурна комуникација, Скопје. 
Весна Мојсова-Чепишевска - предава група предмети од областа на современата македонска литература, како и од областа на книжевноста за деца и македонската култура на Филолошкиот факултет „Блаже Конески“ при Универзитетот „Св.Кирил и Методиј“. Од 2012 година е редовен професор на истиот Универзитет. Од 2002 година работи и како лектор по македонска литература и јазик на Меѓународниот семинар за македонски јазик, литература и култура во Охрид. Член е на ДПМ (Друштво на писатели на Македонија) и на МСК (Македонски славистички комитет).

Области на интерес: македонска литертура и култура, јужнословенски литератури и култури, книжевност за деца.

Wesna Mojsowa-Czepiszewska - wykłada współczesną literaturę macedońską, a także literaturę dziecięcą na Wydziale Filologicznym Blaže Koneski Uniwersytetu Świętego Cyryla i Metodego w Skopje. Od 2012 roku jest profesorem na pełnym etacie na tym samym uniwersytecie. Od 2002 roku pracuje również jako wykładowca literatury i języka macedońskiego na Międzynarodowym Seminarium na temat Języka, Literatury i Kultury Macedońskiej w Ochrydzie. Jest członkiem Macedonian Writers’ Association (DPM) oraz Macedońskiej Akademii Nauk i Sztuki (Macedoński Komitet Słowiański). Obszary zainteresowań: literatura i kultura macedońska, literatura oraz kultury południowosłowiańskie, literatura dla dzieci.

e-mail: vesnamojsova@hotmail.com 
